Chapter 4

\title{
Social and Political Activism amongst British Sikhs: Responses to Issues of Equality and Human Rights-A new way forward?
}

Opinderjit Kaur Takhar

"Former PM sent personal note to Indira Gandhi saying Britain supported India's unity in face of demands for Sikh homeland... Margaret Thatcher gave her Indian counterpart Indira Gandhi Britain's full support in the immediate aftermath of the 1984 Golden Temple raid."

(The Guardian, 15 January 2014)

"The UK government has been accused of creating "appalling delays" to the outlawing of caste discrimination."

(BBC News website, 30 July 2013)

\section{Introduction}

This chapter explores the British Sikh community's responses to two recent events, both related to British Parliament: 1) the alleged involvement of the British SAS (Special Air Service) in the planning of Operation Blue Star ${ }^{1}$ and 2) the lobbying of British Parliament to legislate against caste discrimination under the Equality Act. Both demanded an educated and mature response from British Sikhs in the light of issues surrounding equality and human rights. This study is based on my ethnographic research that I have been conducting since 2010. Here, I analyse my interviews with organisers of both social and political activism in order to explore the effect that media and globalisation have had on the younger generation of British Sikhs.

This chapter examines whether the British Sikh community have taken on a fresh approach when confronted with issues surrounding equality and human rights and explores how youth-led Sikh groups and organisations such as Sikh Federation UK, The Sikh Council UK, the Sikh Network and Kesri Lehar have responded to contemporary challenges (and 
indeed opportunities) by using Sikhi in a sophisticated manner to address such issues politically and socially. I place the collective efforts of such British Sikh organisations, and indeed, of young Sikh individuals, within the wider international context in order to explore whether there are generational trends in the socio-political activism of millennial Sikhs with that of the older generation of Sikhs.

The proposed changes to British legislation in order to make caste discrimination illegal in the United Kingdom has caused much unrest amongst the Hindu, Sikh and Dalit communities in Britain. The pro-legislation organisations are primarily from the Dalit community in Britain and represent Ravidassias, Valmikis, Christians and Buddhists. CasteWatchUK and the Anti Caste Discrimination Alliance (ACDA) have been spearheading the campaign, along with other Organisations which include VODI (Voice of Dalit International), FABO (Federation of Ambedkarite and Buddhist Organisations, and Dalit Solidarity Network. The main opponents of the legislation, the anti-legislation organizations, include Sikh Council UK and the Alliance of Hindu Organisations UK. To some degree, there was unanimity amongst most British Sikh organisations that legislation against caste discrimination was unnecessary under British law. Many Sikh organisations joined forces with the Alliance of Hindu Organisations to declare that 'caste allegiances were on their way out in the UK' and demanded a Sunset Clause. However, the handling of the alleged cooperation between Indira Gandhi and Margaret Thatcher brought issues of leadership and collegiality amongst British Sikhs into question. What became apparent is that there is no one overall authoritative British Sikh organisation or body which represents the community as a whole. Limited understanding by Sikhs of the process for the inquiry requested by the British Prime Minister, David Cameron, may also have added to the chaotic assembling of Sikh Organisations at Parliament. This chapter examines the political engagement of the younger generation of British Sikhs with Britain's policies relating to equality and human rights. 


\section{Legislation against caste discrimination in the UK Single Equality Bill}

The role played by, and attitudes toward, caste amongst Sikhs is a contentious issue, one which almost always raises a heated debate. The Sikh Gurus' teachings on caste are clear; those who are followers of the Gurus should not practice caste discrimination (Takhar 2005; Kalsi 1989). The key Sikh teaching about the imminence of the Divine within each and every human being leaves no scope for discrimination either on the basis of caste or on the basis of gender. The Guru Granth Sahib is very clear on this point, as a hymn of Guru Nanak states:

Recognise the Divine Light within all, there is no caste in the afterlife.

(Guru Granth Sahib, Ang/Page 349)

Guru Nanak’s message was also repeated by his successors. Guru Amar Das writes:

"When you die you do not carry your caste with you. It is your deeds [and not your caste] which will determine your fate" (Guru Granth Sahib, Ang/Page 363)

However, there is a lack of evidence to suggest that the Gurus' social comments on caste were intended to completely eradicate a system which identified individuals with an in-group. The Sikh tradition also maintains that the Gurus, as well as their offspring, all married in accordance with rules around endogamy within the Khatri zat (jati). Nevertheless, Surinder Singh Jodhka has argued that although caste plays a role amongst the Sikhs, it takes on a marked difference in actual practice from its traditional forms amongst non-Sikh communities, writing: “... Sikh caste differs from its more classical antecedents... [and there is no] specific caste group comparable to the kind of division that the textbook view of caste suggests” (Jodhka 2014: 583). The lobbying of Parliament, mostly by Dalit groups, from 2003 onwards, and especially from 2010-2013, to pass legislation in making caste-based discrimination a punishable offence, resulted in British Sikhs re-evaluating their attitudes towards equality based on caste. A historic debate took place on the Sikh Channel in April 
2013 presenting cases both in opposition as well as in support of the anti-caste discrimination legislation. The Sikh Council UK, Hindu Council UK (now absorbed within a larger group currently known as the Alliance of Hindu Organizations) and Dalit organisations such as CasteWatch UK and Anti Caste Discrimination Alliance had all drafted press releases ahead of the debate to clearly highlight their particular organisation's stance toward the legislation. The Sikh Channel debate took place a few days before the legislation was passed on 23 April, 2013 when British Parliament agreed to an amendment on caste to the Enterprise and Regulatory Reform Bill. However, the implementation of this legislation has yet to move forward, mostly because of opposition from Sikh and Hindu communities in Britain who argue that there is simply not enough evidence to suggest that caste-based discrimination is an issue amongst South Asians living in Britain. Their concern is also that the implementation of the legislation would institutionalise caste distinctions amongst South Asian Britons and, more so, their belief is that caste discrimination does not take place in Britain. The response from Dalit individuals and pro-legislation organisations is that nonDalit South Asians living in Britain are purposefully turning a blind eye to caste-based discrimination. The concern from Dalit organisations is that they left India to escape the overt discrimination they faced as Dalits on a daily basis. For many Dalits, the words of Omprakash Valmiki (in his 2003 autobiography Joothan) are reminiscent of the sentiment and emotion behind Dalit activism in support of the legislation over the harsh treatment that they had endeavoured to leave behind in India:

"Dalit life is excruciatingly painful, charred by experiences... We have grown up in a social order that is extremely cruel and inhuman. And compassionless towards Dalits.” (Valmiki 2003: xiii).

A number of Dalits supporting the legislation also identify themselves as Ravidassi Sikhs and Valmiki Sikhs. The Ravidassias, also referred to as Ravidassi, acknowledge allegiance to Ravidass as their Guru (see Takhar 2005: chapter 4). There are forty-one hymns of Ravidass, 
referred to as Bhagat (devotee) by Sikhs at large, in the Guru Granth Sahib. His community of followers, like himself, are exclusively from the chamar caste (zat) of Dalits. The Valmikis are from the chuhra zat of Dalits and claim that this was also the caste of Valmiki, the author of the Hindu epic, the Ramayana (see Takhar 2005: chapter 5). These identities are far from being rigid however, as the results of the 2011 UK Census highlighted (Takhar 2011; 2014).

My research has attempted to make sense of the paradox of attitudes from both procaste legislation organisations and individuals as well as anti-caste legislation organisations and individuals. If the teachings of the Gurus are taken as a yardstick, then surely Sikh organisations should be welcoming of the legislation around caste-based discrimination? However, the main concerns of the Sikh Council UK are over terminology and definitions used in the various reports highlighting the extent of caste-based discrimination in the UK. The Sikh Council maintains that the prolonged implementation of the legislation is welcome in order to give time for it to be thought out since they believe there are many pitfalls in the current definitions of caste within the legislation. The Sikh Council UK adamantly assert that the methodology employed to produce the NIESR report, was flawed as it only interviewed victims of caste-based discrimination from Dalit backgrounds. The National Institute for Economic and Social Research (NIESR) appointed Hilary Metcalfe and Heather Rolfe to produce a report on Caste Discrimination and Harassment in Great Britain (2010). ${ }^{2}$ The NIESR Report found that there is significant evidence of caste based discrimination in Britain in the areas of employment, education and in the provision of care services. The Report's recommendation was that legislation is necessary in order to punish perpetrators of caste discrimination in the three areas highlighted above. The Report suggested that a revision to the definition of 'race' in the Equality Act 2010 would accommodate the amendment to 
include caste. Subsequnetly Subsequently, the Sikh Council's Press Release in May 2013 stated:

In line with the teaching of Guru Nanak Dev Ji, the Sikh Council UK fully supported the sentiments of creating a casteless and equal society but raised serious concerns about the impact of ill-considered legislation based upon flawed research. Following extensive lobbying of Minister, Lords and MPs the Sikh Council UK has been credited with taking a measured, thoughtful and pragmatic approach in helping resolve a complex issue.

Based on my interviews with a number of leaders from organisations in support of the legislation, the view is that the obstacles in the implementation of the legislation are a question of Sikhs in particular having to openly deal with the hypocritical distance between Sikh teachings and actual practice. Opponents of the legislation (mainly the British Sikh and Hindu communities) believe that education, rather than legislation, is the best way to tackle caste based prejudice and discrimination, if it does indeed exist at all. However, a number of educational programmes instigated by the Sikh and Hindu communities have failed to achieve their goals. A recent report by the Equality and Human Rights Commission has also failed to convince the opponents to rethink their stance since the Hindu and Sikh communities have found these unsatisfactory as, in their opinion, they simply echo the NIESR report. Opponents of the caste legislation thus argue that the legislation is unnecessary in view of their firmly held conviction that caste-based identification, and indeed, any associated prejudice, are “on their way out” amongst the younger generation of British South Asians. Although the British Hindu community united under one umbrella organisation with the formation of the Alliance of Hindu Organisations (AHO), the Sikh Community had a number of 'spokespersons' representing the Sikh view of opposition to the legislation. The main voice, though not the only voice in opposition to the legislation, was that of the Sikh Council. Importantly, their opposition is not an objection to the principle of equality and human rights of all per se, but an insistence that the term 'descent' is more appropriate as a protected category using the term 'caste' to amend the Equality Act 2010. 
Their view is largely based on the assumption that Sikhi rejects the caste system and therefore any prejudice and discrimination associated with the caste system does not apply to the Sikhs. The Sikh Council UK further cite that the United Nations' definition of racism covers 'descent' and this therefore, is a far relevant term to be used in order to protect against any unintended consequences of the legislation for the Sikh community.

Among the various South Asian communities in the UK, there are long-established traditions, conceptions, and associations based on caste. Although Guru Gobind Singh's initiation of the Khalsa institutionalised the use of Singh and Kaur as surnames in 1699 CE, many Sikhs continue to use their family names as a means of identification. This does not, and should not, be equated with such Sikhs having a 'caste-ist' mentality that carries the stigma of either pollution or purity. A number of young British Sikhs whom I have interviewed have adamantly asserted that there is nothing wrong with identifying as Jat, Ramgharia, Bhatra, Ravidassi, and so forth. Their viewpoints are particularly relevant when bearing in mind that much of the work carried out on caste, especially in the Indian context, tends to demonise it without exploring its psychological relevance amongst young British Sikhs. Having said this however, I also appreciate that much work on caste has been undertaken from an empirical and ethnographic approach which highlights the harsh discrimination faced by victims from the Dalit community in particular (Nesbitt 1994; Gorringe and Rafanell 2007).

In order to make sense of the role, if any, played by caste amongst Sikhs, I took part in a social psychological study by interviewing young British Sikhs in order to gather qualitative data on a number of themes relating to how they identified themselves (Jaspal and Takhar 2016). We used the Identity Process Theory, which explores the protection of identity at an individual level (see Breakwell 1986) to analyse the responses we gathered. The findings of our research further confirm the complexity of how caste operates at a practical 
level amongst the Sikhs, specifically British Sikhs in the context of the research we undertook. Contrary to popular understandings of caste, identification with a caste is not synonymous with caste-based prejudice and discrimination (Jaspal and Takhar 2016).

The Sikh Council has insisted on a 'Sunset Clause', which states that the legislation should be valid for a period of ten to fifteen years at maximum, since, ostensibly, caste will have no relevance at all amongst South Asians beyond that time frame. To some degree they are correct, mixed caste marriages are becoming more acceptable in the British Sikh community, although the preference amongst the older generation is for endogamy. From the personal interviews I have carried out over the past decade, young British Sikhs adamantly assert that they have never seen, experienced or carried out caste-based discrimination in their adherence to the principles of Sikhi. Many of these young Sikhs have however offered to meet victims of caste-based discrimination to hear about their experiences first-hand. So for many British Sikh millennials, open dialogue is the way forward, rather than dismissing casteist attitudes within their community as being non-existent. The millennial generation are also more likely to marry out of caste as a practical step towards achieving a caste-less Panth. The older generation of British Sikhs however, are not so receptive to overturn the system of endogamy. Dalit individuals whom I have interviewed, however, have often responded by remarking that young British Sikhs turn a blind eye to such issues.

The complexities around legislating against caste-based discrimination in Britain have been discussed at length by Prakash Shah (2015). His argument largely focuses on the problematic issues relating to the legal framework within which the legislation is positioned. Interestingly, his discussion gives credence to the anti-caste-legislation attitudes and draws on extended ethnographic research on Hindu and Sikh perspectives. His work echoes a number of the concerns put forward by the Sikh Council UK in emphasizing that caste discrimination is not an issue in the UK (for a detailed insight into the Sikh Council UK’s views, see Jaspal 
and Takhar 2016). Another report, which in many ways supports the Sikh Council's conviction that caste plays no role amongst British Sikhs, is the British Sikh Report (BSR) $2013^{3}$ which has been produced annually since 2013 to provide an overview of the needs and challenges faced by the British Sikh community. The report covers a number of areas, including education, wealth, occupation and caste According to the BSR 2013, 61.2\% of the 662 respondents indicated that caste-related issues are of no concern to them. , Indeed, it is the millennial British Sikh generation whom have been most vocal in their opposition to the caste legislation in Britain as being unnecessary. Case Studies from pro-legislation organisations however, paint a very different picture and highlight that Dalits living in the UK have been victims of caste-based discrimination as a result of prejudice on the part of Sikhs.

\section{Indira Gandhi and Margaret Thatcher's collaboration over Operation Blue Star}

I shall now go on to discuss the British Sikh community's response to another recent event, again relating to British Parliament: the alleged involvement of the British SAS (Special Air Service) in the planning of Operation Blue Star, the 1984 attack on the Sikhs' most revered holy shrine in Amritsar, Punjab that resulted in the massacre of thousands of innocent worshippers ${ }^{4}$. The revelations in January 2014 of the SAS's alleged involvement in the planning of the attacks on the Harmandir Sahib in June 1984 rapidly mobilised young British Sikhs to demand justice for the abuse of the human rights of thousands of Sikh victims during Operation Blue Star and the subsequent genocide of thousands of Sikhs in Delhi in November 1984 (for a detailed account of the events in Delhi, November 1984, see Mitta and Phoolka, 2007; Singh Pav, 2017)._Shinder Thandi (2012) has observed that Sikhs in Britain have the networks to be able to mobilize themselves quickly over issues concerning events in Punjab and elsewhere that concern Sikhs. Sikh utilisation of multimedia has been an 
important tool via which to do this. Almost immediately the Sikh-themed TV Channels were covering various stories and interviewing individuals about their responses to the revelations. On the surface, there appeared to be unity amongst the British Panthic organisations and Jathebandhis (political organisations) in terms of demanding an inquiry into the full extent of collaboration between the Indian Government and British Government in the planning of Operation Blue Star.

However, a limited understanding of the process for the inquiry and a lack of clear terms of reference resulted in issues around authority amongst the leaders of the various British Sikh Organisations. The situation was unfortunately one which displayed a lack of leadership within the British Panth as a whole. What resulted on the part of the Conservative Government was a rushed internal review carried out by Sir Jeremy Heywood, the Cabinet Secretary. A number of pertinent files relating to the SAS's visit to India at the time of Operation Blue Star also mysteriously went missing, whilst others were withheld. The internal inquiry concluded that SAS involvement was minimal and there was no indication that the Indian Government took their advice. The shambolic approach to the inquiry by Heywood left the majority of concerned Sikhs totally dismayed. How, as British citizens, could their own government advise an attack on their holiest of shrines? Many young British Sikhs' posts on social media questioned whether a British Sikh identity under such revelations has any meaning at all and how David Cameron and his cabinet advisors got away with such a problematic inquiry.

My personal correspondence with key British Sikh individuals at the time shed some light on the situation. The issue in this case, unlike that of caste legislation, was the overall anarchic approach of every single British Sikh organisation claiming to be the voice of the British Panth. In actual fact, there was no one voice that could successfully relay the emotions and sentiments of the British Panth back to David Cameron. The lack of an 
authoritative voice which speaks for Sikhs in the various countries of their diaspora, is not unique to the British situation. Issues around Panthic authority in terms of both discursive and political representations, exist because there is simply no "obvious apex authority or ecclesiastical hieracrchy to represent Sikh collective interests to outside parties (Dusenbery 2008: 318), this has resulted in often competing claims to authority amongst the various organisations and Jathebandis within the Panth. Nevertheless, based on my ethnographic work amongst the British Panth, I have observed that the tone has changed, albeit slightly, since January 2014. There is more of an understanding of political processes with more young British Sikh professionals wanting to get involved, drawing on international human rights discourse to demand justice and to pressure the United Nations to recognise the massacre, torture, and rape of Sikhs in 1984 as genocide. Young British Sikhs want to see change in the way they and their community are portrayed in social media to the rest of the world. The Sikh Network (formed in November 2014) is reflective of young British Sikhs, many from well educated and professional backgrounds, getting involved with issues that matter to the wider Sikh Panth. Jas Singh, who leads the Sikh Network, and is also Advisor to the Sikh Federation UK, organises the annual Freedom Rally in June through Central London to protest against the lack of justice for victims of the 1984 Sikh Genocide. Jas is an example of a professional young British Sikh millenial who feels it very much his duty to take practical steps in terms of the issues that matter to him. During an interview he commented :

“... [the] cornerstone of Sikhi is about being an activist, started by Guru Nanak Dev Ji, so I believe you are not being true to Sikhi unless you awaken the activist within. Becoming tired of being one of the typical Sikh observers criticising from the sidelines, I decided to actually do something!" Interviewed in person by the author at Guru Arjan Dev Gurdwara, Derby, UK, $2^{\text {nd }}$ February 2015.

In my fieldwork, I have observed an increase in young professional British Sikhs being involved in political activism. This has not gone unnoticed by the British and Indian Governments, as details have emerged of an alleged meeting in London between the Indian 
and UK Governments on 15 January 2015 to discuss the rise of radicalisation amongst British Sikhs ${ }^{5}$.

A number of key questions are pertinent: Is Sikh political activism being termed as radicalisation? Can we identify a generational trend amongst Sikh political activists? What has caused this apparent increase in younger Sikhs becoming involved with political activism? Interestingly, in April 2013 the National Union of Students (NUS) showed its support for demanding justice for the victims of the Sikh Genocide of 1984. This could suggest that University Sikh Societies are strengthening political activism amongst Sikh University students. There has been an increase in seminars on the 1984 Sikh Genocide across Sikh Student societies for the past couple of years. Very often these seminars are also followed up with talks around the issue of Sikh separatism in the form of Khalistan. The extent to which the demand for justice often becomes associated with the demand for Khalistan is clearly highlighted by Darshan Singh Tatla:

Certainly, the 1984 tragedy has become a 'critical event' forcing many Sikhs to examine the community's standing in the global world of nation states and to formulate their relationship with the Punjab and post-colonial Indian polity. A major debate has emerged around the need for a sovereign state with various responses. (Tatla 2014: 509).

However, it is equally true that support or rejection of a Sikh separatist state also divides many young British Sikhs. Not all British Sikh activists necessarily regard their activism as being related to Sikh ethno-nationalism (for a detailed discussion about ethno-nationalism in the Sikh context, see Gurharpal Singh, 2001). Although the majority of activists I have spoken to at rallies, demonstrations, and protests wholeheartedly support a UN led inquiry into the 1984 Sikh Genocide, it is the Khalistan issue that divides them. Importantly, I have seen an increase in young professional British Sikhs adamantly expressing their views that Khalistan is the only solution to preserving Sikh Heritage. These young Sikhs have carried out their own research and formulated their own views on the topics which affect their 
relationships with their ancestral homeland of Punjab and thus strengthens Darshan Singh Tatla’s claim that:

Undoubtedly, a defining characteristic of overseas Sikhs (which has contributed to their status as diaspora) is its abiding concern and involvement with the land of its origin... Overseas Sikhs have maintained a close relationship with their former villages, the region and with the Punjab as a whole in many different forms: through social, economic and philanthropic linkages. Overseas Sikhs have kept abreast of events in Punjab through the Punjabi media, visits and other channels of communication (Tatla 2012: 3-4).

These same professional Sikhs are asking for informed debates around Sikh separatism and Khalistan as an actual state, not one that is only utopian or imagined. Other Sikh professionals actively involved in lobbying the UN to recognise the massacres of Sikhs in 1984 as genocide firmly assert that shouted slogans of "Khalistan Zindabad" puts them off from attending political events. A number of scholars in the past have stated that the Khalistan movement reached its peak in the 1990s and is today barely existant (Mahmood 2014; Tatla 2012; Singh, Gurharpal 2001). According to Chima (2002), Sikh separatism "will not re-emerge in Punjab in the near future" (p. 19). However, I have found the Khalistan movement to have a renewed vigour amongst British Sikhs, old and young, male and female. Shani has noted that:

Both 'homeland' and 'diaspora' may be regarded as indivisible parts of a global Sikh qaum which sees the establishment of an independent sovereign state as merely one strategy used to secure recognition of its cultural and religious particularity (Shani 2008: 8).

This echoes the views held not only by British Sikhs, but by Sikhs in the broader diaspora, as to why a separate state is the only solution to the survival of Sikhi and Sikhs in the 'homeland'. The ten failed commissions and committees led by the Indian Government (see Mitta and Phoolka 2007) to carry out inquiries into the murder, rape, and torture of Sikhs in Delhi in November 1984 provide further push factors for young British Sikhs (along with Canadian and American Sikhs) both in the lobbying of the UN, as well as the Khalistan 
movement. These young Sikhs look to Jarnail Singh Bhindranwale as their inspiration-the image of Bhindranwale has indeed become a symbol for the lack of justice to the victims of the 1984 Sikh genocide (for further discussion on this topic see Singh and Purewal 2013). Although it is a commonly held belief amongst many Sikhs that Bhindranwale himself did not demand support for Khalistan, he is nevertheless remembered as having made the statement that if the Harmandir Sahib were ever to be attacked by the Indian Government, the foundations for Khalistan would be laid (Mahmood 2014: 578). British Sikh political activism has much in common with activism by Sikhs, for Sikhs, taking place on a global level. Examples of similar goals relate to the petitioning of the UN to declare the massacre, torture and rape of Sikhs in Delhi in 1984 as a Genocide. In contemporary times, much political activism is related to the policies of particular states, particularly against its minority communities (Keck and Sikkink 1998). One of my interviewees, Jas Singh from the Sikh Network and the Sikh Federation UK adamantly disagrees with the notion that the Khalistan movement is today barely acknowledged amongst Sikhs:

I disagree, the movement has just changed, the issues and social injustices still occur every day, and never addressed, so how can the solution be forgotten? The cause was demonised and silenced by the Indian Government propaganda, and now as the truth is becoming clear, we now need to establish the social and civic demands and legal right for the Sikh nation to be free, whether that remains within or without India, that is up to the government on how they respond and ultimately the people of Punjab. Many hold the desire to be free within their hearts both abroad and in India. However, until they are free to express their view without the constant fear of arrest, torture or death, the struggle will continue to boil within. Interviewed in person by the author at Guru Arjan Dev Gurdwara, Derby, UK, $2^{\text {nd }}$ February 2015.

To be politically engaged and politically active is one of the key tenets of the Sikh faith through its Miri-Piri principle, which translates into active participation in worldly affairs alongside one's spiritual journey. This is clearly represented in the Harmandir Sahib complex in Amritsar which also houses the Akal Takhat - the Headquarters of the SGPC 
(Shiromani Gurdwara Parbandhak Committee). The complex represents 'temporal power in balance with the spiritual' (Kalra 2014: 262).

The overall majority of young British Sikh political activists I have spoken to are keen to mention that it is being Sikh which is an important contributing factor to their activities and support for campaigns for Justice. For them, Operation Blue Star was an attack on their faith. This sentiment is further detailed in Joyce Pettigrew's work (1995), which also provides the introductory remarks for the 'Candle in the Dark' exhibition produced by the National Sikh Youth Federation UK:

"The army went into [the] Darbar Sahib not to eliminate a political figure or a political movement but to suppress culture of a people, to attack their heart, to strike a blow at their spirit and self-confidence” (p. 8)

Hence, unsurprisingly, the revelations of British Government involvement in Operation Blue Star came as a huge shock in terms of what it meant to be both British and Sikh around the time of the revelations in January 2014. The sense of betrayal from the British government occupied Sikh media, especially in light of Sikh contributions to the British Army during both World Wars. It is important to understand how identity is formed and negotiated depending on how a state protects the interests of individuals and communities, especially its minority communities. Sikhs constitute less than $2 \%$ of the Indian population. After 1984, many Sikhs living in Britain ceased to identify as 'Indian' and therefore their 'Britishness' became a strong indicator of their identity. Interestingly, according to the British Sikh Report 2013, 95\% of British Sikhs reported that they were proud of their British-ness. After March 2015, however, this dialogue on British Sikh identity has almost become non-existent. Reaction to the allegations demanded an educated and mature response from British Sikhs in the light of issues surrounding equality and human rights.

In June 2014, the 1984 Freedom Rally in Central London (organised annually by the Federation of Sikh Organisations or FSO) gathered an estimated attendance of 80,000 
(mostly Sikhs) under the theme of 'Truth, Justice, Freedom'. Sikh Student Societies in British Universities under the guidance of the British Organisation of Sikh Students (BOSS) () were actively engaged to mobilise Sikh students. The role of social media and the Sikh Channels in the mobilisation of British Sikhs has been immense. A number of issues affecting British Sikhs in more recent times-from the revelations of the SAS involvement in the planning of Operation Blue Star to the hunger strikes by Bhai Gurbaksh Singh—have united Sikh millennial activists across the globe in their engagement with wide stream media and social networks. The recently formed Sikh Network in the UK has also been responsible for producing the "Sikh Manifesto 2015-2020", 6 a document which highlights ten key areas of concern to the British Sikh Community. The objective of the document was to provide the British Sikh Panth with a coherent outline of Sikhs' expectations from the next Government, ahead of the 7 May 2015 General Elections in the United Kingdom. The "Sikh Manifesto" was officially launched in British Parliament on 26 February 2015. The Sikh Network claims to be a platform for uniting Sikh political activists in the UK. One of the key sections of the Sikh Manifesto is for the British Government to commission an independent public inquiry into the UK Government's actions in the lead up to and after the 1984 Sikh Genocide. The producing of the "Sikh Manifesto" is a new way of giving political activism in the United Kingdom a shared focus. Not all British Sikhs are expected to agree with all of its ten key areas, but they are encouraged to actively share their thoughts with Parliamentary Candidates regarding the points that resonate with them.

It has been refreshing to see an increase in Sikh females, particularly from the younger generation, visibly taking an active role in protest, awareness events, and rallies in a traditionally male-dominated Sikh arena. Aelst and Walgrave (2001) have indeed noted a marked increase in activism by females (regardless of faith, belief and non-belief) across the globe. The Sikh Organisation for Prisoner Welfare (SOPW) is a prime example of females 
taking the lead in stage presentations and organising fund raising events. SOPW, a British organisation, has now been rebranded as Sikh Relief. Sikh Relief is an excellent example of the practical ways in which the egalitarian teachings of Sikhi, particularly in relation to gender equality, are being visibly practised as more young professional Sikh females view the Sikh political environment as a social space in which they have a role to play. The current scene in the UK echoes Doris Jakobsh's words:

In essence, gender constructs are evolutionary, they emerge and develop with the shifting needs of the community within which they unfold. They are also susceptible to the forces surrounding them, be these political, economic, social or cultural (Jakobsh 2003: 238).

Millenial Sikh female activists are proudly asserting their equal responsibility to live by the Miri-Piri concept. In many respects, South Asian women generally have been "politically active, even under the most oppressive circumstances,” as noted by Shaminder Takhar (2007: 123). She goes on to ponder "....we... need to ask... whether South Asian women face major obstacles to political activism because of the intersection of gender, racism, and culture?” (2007: 124). From my observations, with the increase in Sikh groups and networks run by the younger generation of British Sikh political activists, Sikh women are increasingly finding acceptance, and also leadership roles, within political circles. This is a result of socio-cultural changes in attitudes towards gendered roles amongst millenials of the Sikh diaspora, particularly in Britain, Canada and the USA through the many activist groups prevalent in contemporary society. These organisations are actively encouraging women to take an equal stand in lobbying for Sikh causes in both the religious as well as political spheres. The traditional Jathebandi organisations, however, have some way to go in at least attempting to address the overt gender imbalance amongst their members.

The findings of the British Sikh Report (BSR) $2015^{7}$ raised some interesting responses from informants in relation to the revelations of January 2014. The gendered 
perspective towards the SAS involvement in the planning of Operation Blue Star, according to the BSR 2015, indicate that $20 \%$ of males were uncertain about the impact that the revelations had made upon them personally. In comparison, 37\% of female respondents were unsure as to how they felt about the revelations as British Sikhs. Nevertheless $24 \%$ of females indicated that the revelations would play a significant role in their decision as to which Party they will vote for, as compared to $36 \%$ of males who indicated the same response to the question. The BSR 2015 analysis of the statistics obtained from respondents illustrates that:

For some Sikhs, what happened in 1984 remains a highly emotive topic which continues to be relevant today. However, it should be noted that not all British Sikhs share the same strong emotions about the events of over 30 years ago, as can be noted from these findings.

Clearly, there is a need for further research into the current British Sikh political activist environment in order to be able to gather and analyse why young millenial British Sikhs become involved in political activism. It will be interesting to analyse the degree to which such activism relates to events of the "homeland", since according to Nijhawan (2016), Sikhs in the diaspora create "social imaginaries" which gives them a sense of belonging to both the "homeland" (through images associated with the Sikh Genocide 1984), as well as their countries of settlement (p. 44). I quote below three further responses from British Sikhs, as stated in the BSR 2015, in relation to the impact of the revelations upon their voting decision in the May 2015 General Elections.

Those were tragic days, there was a sense of helplessness in the UK felt by Sikhs. To know that the UK government at the time had an input into it (even very small) is rather sickening. We are still waiting for justice for the Delhi riots where thousands were killed.

It's important that the Sikh community get the correct answers and reflections into what truly happened in 1984 . Without the support and backing of a political party this may be difficult to achieve. 
I would like full disclosure of the facts therefore allowing the whole truth to be revealed in an honest and transparent way. The government needs to be compassionate, righteous, brave and firm to show the complete honest truth.

The testimonies above clearly voice a sense of betrayal by the then British Prime Minister, Margaret Thatcher, and her Government and clearly illustrate that millenial Sikhs, as well as Sikh activist organisations, have been demanding a full enquiry into the extent of the British Government's role in the planning of Operation Bluestar. Another recently produced report, the UK Sikh Survey 2016, further evidences such activism in its findings that 92\% of British Sikhs believe there should be an independent public enquiry "to establish the full facts about UK Government involvement” in Operation Bluestar (p. 14). ${ }^{8}$ The UK Sikh Survey 2016 is built around the ethos of the Sikh Manifesto, also produced by the Sikh Network.

The Sikh Network's Sikh Manifesto: 2015-2020 which was based on nationwide consultations amongst British Sikhs, lists both an Independent public inquiry into the UK government's involvement in planning Operation Blue Star and also asks for a United Nations-led inquiry into the 1984 Sikh genocide. Therefore, such issues are of concern to a significant number of British Sikhs. Their disengagement with such issues needs to be explored in terms of whether family, the gurdwara, and their broader surroundings have roles to play in a young British Sikh's decision to become involved with political activism relating to events in Punjab, Delhi, and elsewhere in India. Do university Sikh societies have a role to play? The National Union of Students, a national body representing University students in Britain, is also supporting and endorsing the '1984 Yes, it's Genocide' ${ }^{9}$ campaign, which is asking the United Nations to investigate the truth into the extent of the massacre, torture, murder and rape of the Delhi Sikhs in the aftermath of Indira Gandhi's assassination by her two Sikh bodyguards on 31 October 1984

There has been a great deal of scholarship on political activism within the Muslim community in Britain (see, for example: Nagel \& Staeheli, 2011; Bolognani \& Statham, 
2013; Allen, 2010). In comparison, there is little data or statistics available relating to young British Sikhs. For example, can an age range be identified from those who attend rallies, protests and so forth? Such data would be extremely valuable in exploring gender and generational trends within British Sikh activism. A study by Nagel and Staeheli (2011) seeks to understand the role of religion amongst activists who identified as Muslim. They found that many of their respondents "were deeply concerned about the misrepresentation of Islam in the West. Respondents however, were far from unified in their views on religion as a basis for political action and mobilisation” (438). Similar trends can be identified amongst young millenial British Sikh activists. Events relating to the attack on the holiest of Sikh sites stirs up emotions amongst many of the young Sikhs I have spoken to, including those who were born after 1984. Sentiments very much express the opinion that Operation Bluestar was a direct attack on the Sikh community per se, under the pretence of the Indian Government to control terrorism as a result of the increasing popularity of Sant Jarnail Singh Bhindranwale. Adversely however, Bhindranwale’s popularity amongst millennial Sikhs is ever increasing and he represents the injustice that is felt by millions of Sikhs across the world in the cover up of events leading to Operation Bluestar and the events which followed, in particular the media and Government’s cover up of the Sikh Genocide of 1984.

\section{Conclusion}

It is clear that the British Sikh community has made the most of social space by taking to the streets in mass demonstrations to raise awareness of issues that matter to them. The Miri-Piri concept in Sikh teachings has its role to play in motivating the activist spirit amongst British Sikhs, and indeed, Sikhs worldwide. The increase in Sikh organisations, both in Britain and North America, for example, indicate that young Sikhs are taking the lead in 
finding new ways for engaging with political and human rights issues. A criticism of the Sikh Manifesto: 2015-2020 has been that it does not cover caste discrimination legislation amongst its ten points of action. It is well to note here that the Sikh Manifesto was based on extensive outreach with the British Sikh community in highlighting issues that mattered to THEM. The community itself does not believe that caste itself poses any issues within the community and is therefore not an area that needed to be addressed by the incoming Government. . On the whole, the British Sikh community has generally opposed caste based legislation due to the factors mentioned earlier. On the other hand, the revelations in January 2014 of British involvement in the attacks on the Harmandir Sahib complex is an emotional issue amongst British Sikhs and one that has continued to occupy millennial British Sikh activism in contemporary society. Therefore, collective social memory around 1984 has shaped much of the activism within the Sikh community at a global level. The millennial generation of Sikh activists have inherited the trauma of memory from older Sikhs and therefore, in this respect, strengthens the relationship between violent events and temporality (Nijhawan 2016: 27). So, in terms of caste prejudice, the experiences of the majority of non-Dalit Sikhs indicates that caste plays no role in British society amongst Sikhs and hence they largely oppose the implementation of the legislation. Operation Blue Star and the consequent Genocide of Sikhs in 1984, however, links the Panth emotively on an issue concerning the human rights of the victims and their families. Hence, there is overall support from the British Sikh community, especially the millennial generation, for a public inquiry into the full extent of the British Government's involvement with the attacks. This issue is indeed one that affects the British Sikh community at large, across generations, as indicated by its inclusion in the Sikh Manifesto for 2015-2020. 


\section{References}

Aelst, Peter Van and Stefaan Walgrave. 2001. 'Who is that (wo)man in the street? From the normalization of protest to the normalization of the protester.' European Journal of Political Research. 39: 461-486.

Allen, Chris (2010). Islamophobia. Aldershot: Ashgate

Bolognani, Marta \& Paul Statham. (2013). "The changing public face of Muslim associations in Britain: Coming together for common ‘social’ goals?” Ethnicities. 13: 2, 229-49.

Breakwell, G. M. (1986). Coping with threatened identities. London: Methuen.

Chima, Jugdep S. (2002) "Back to the Future in 2002?: A Model of Sikh Separatism in Punjab” in Studies in Conflict \& Terrorism, 25: 1, 19 - 39.

Dusenbery, Verne (2008). Sikhs at Large: Religion, Culture and Politics in Global Perspective. New Delhi: Oxford University Press.

Gorringe, H. \& Rafanell, I. (2007). “The embodiment of caste: oppression, protest and change”. Sociology, 41(1), 97-114.

Jakobsh, Doris (2003). Relocating Gender in Sikh History: Transformation, Meaning and Identity. New Delhi: Oxford University Press.

Jaspal, Rusi and Opinderjit Kaur Takhar (2016). "Caste and Identity Processes among British Sikhs in the Midlands”. Sikh Formations: Religion, Culture Theory. 1-16.

Jacobson, J., 1(998). Islam in Transition: Religion and Identity amongst British Pakistani Youth. London: Routledge.

Jodhka, Surinder S. (2009) "Sikhs in contemporary times: Religious identities and discourses of development” in Sikh Formations, 5(1), 1-22.

Jodhka, Surinder S. (2012) Caste: Oxford India Short Introductions. New Delhi: Oxford University Press.

Jodhka, Surinder S. (2014) “Changing Manifestations of Caste in the Sikh Panth” in Singh, Pashaura and Louis Fenech (Eds). The Oxford Handbook of Sikh Studies. Oxford: Oxford University Press, pp. 583-593.

Kalsi, S.S. (1989). The Sikhs and caste: a study of the Sikh community in Leeds and Bradford. Unpublished doctoral dissertation, University of Leeds, UK.

Kalra, Virinder (2014) "Secular and Religious (Miri/Piri) Domains in Sikhism: Frames for Sikh Politics” in Singh, Pashaura and Louis Fenech (Eds). The Oxford Handbook of Sikh Studies. Oxford: Oxford University Press, pp. 262 - 270.

Keck, M. and K. Sikkink, 1998. Activists beyond Borders - Advocacy Networks in International Politics. Ithaca, NY: Cornell University Press. 
Mahmood, Cynthia (2014) “Khalistan’ as Political Critique” in Singh, Pashaura and Louis Fenech (Eds). The Oxford Handbook of Sikh Studies. Oxford: Oxford University Press, pp. $571-582$.

Manoj Mitta and H. S. Phoolka (2007). When a Tree Shook Delhi: The 1984 Carnage and its Aftermath. New Delhi: Roli Books.

Miller, Phil (2017) Sacrificing Sikhs: The Need for an Investigation. Sikh Federation UK.

Nagel, Caroline \& Lynn Staeheli. (2011). "Muslim Political Activism or Political Activism by Muslims?” Identities: Global Studies in Culture and Power. 18, 437-58.

Nesbitt, E. (1994). Valmikis in Coventry: the revival and reconstruction of a community. In R. Ballard (ed.) Desh Pardesh. The South Asian Presence in Britain (pp. 117-41). London: Hurst and Co.

Nijhawan, Michael (2016). The Precarious Diasporas of Sikh and Ahmadiyya Generations: Violence, Memory, and Agency. New York: Palgrave Macmillan.

Pettigrew, Joyce (1995) The Sikhs of the Punjab.London: Zed Books.

Sato, K. (2012)” Divisions among Sikh Communities in Britain and the Role of Caste System: A Case Study of Four Gurdwaras in Multi-Ethnic Leicester". Journal of Punjab Studies, 19(1), 1-26.

Shah, Prakash (2015). Against Caste in British Law: A Critical Perspective on the Caste Discrimination Provision in the Equality Act 2010. Basingstoke: Palgrave Macmillan.

Shani, Giorgio (2008). Sikh Nationalism and Identity in a Global Age. Abingdon: Routledge.

Singh, Gurharpal (2001) “The Limits of 'Conventional Wisdom': Understanding Sikh Ethnonationalism” in Shackle, C., G. Singh, and A. Mandair (Eds) Sikh Religion, Culture and Ethnicity. Surrey: Curzon Press.

Singh, Jasjit (2017) “The idea, context, framing and realities of 'Sikh radicalisation' in Britain: Full Report.” London: Crest.

Singh, Pashaura and Louis Fenech (Eds). The Oxford Handbook of Sikh Studies. Oxford: Oxford University Press.

Singh, Pav (2017). 1984: India’s Guilty Secret. London: Kashi House.

Singh, Pritam and Navtej Purewal (2013) “The resurgence of Bhindranwale's image in contemporary Punjab”. Contemporary South Asia, 21:2, 133-47.

Smith, A. D (1999). Myths and Memories of the Nation. Oxford: Oxford University Press.

Soni, Sharad (2013) "Gauging the Implications of the Wisconsin Sikh temple shooting”. Asian Ethnicity. 14: 1, 106-109. 
Tatla, Darshan S. (2013) “A Sikh Manifesto? A Reading of the Ghadar Poetry”. Punjab Past and Present. 44 (1): $61-81$.

Tatla, Darshan S. (2012) “The Unbearable Lightness Of Diasporic Sikh Nationalism! From Anguished Cries Of ‘Khalistan’ To Pleas For 'Recognition”. Sikh Formations: Religion, Culture, Theory. iFirst: 1-27.

Takhar, Opinderjit Kaur (2005) Sikh Identity: An exploration of groups among Sikhs. Aldershot: Ashgate.

Takhar, Opinderjit Kaur (2011) "We are not Sikhs or Hindus: Issues of Identity among the Valmikis and Ravidasias in Britain” in Singh, Pashaura (ed ) Sikhism in Global Context. New Delhi: Oxford University Press.

Takhar, Opinderjit Kaur (2014) "The Place of Scripture in the Trajectories of a Distinct Religious Identity among Ravidassias in Britain: Guru Granth Sahib or Amritbani Guru Ravidass”. Journal of Contemporary Religion, 29:1, 105-120.

Takhar, Opinderjit Kaur (2014a) "Sikhi(sm) and the Twenty-First Century Sikh Diaspora" in Lewis, C. And D. Cohn-Sherbok (Eds) Sensible Religion. Aldershot: Ashgate.

Takhar, Shaminder (2007) "Expanding the boundaries of Political Activism”. Contemporary Politics. 13: 2, 123-137.

Thandi, Shinder (2012) “Migration and Comparative Experiences of Sikhs in Europe” in Jacobsen, Knut and Kristina Myrvold (eds) Sikhs Across Borders: Transnational Practices among European Sikhs. London: Continuum.

Valmiki, Omprakash (2003) Joothan: An Untouchable's Life (Translated into English by Arun Mukherjee). New York: Columbia University Press.

\section{Notes}

\footnotetext{
${ }^{1}$ Operation Bluestar refers to the Indian Government's attack on the Harmandir Sahib complex in Amritsar on 6 June 1984. Harmandir Sahib, also known as the Golden Temple, is the most revered Sikh religious site, constructed under the Guruship of the fifth Sikh Guru, Arjan. The, then, Indian Prime Minister, Indira Gandhi, justified the attacks as necessary in order to control an increasing hostility towards the Indian Government as a result of the popularity of Sant Jarnail Singh Bhindranwale amongst the Sikhs. Indira Gandhi was assassinated by her two Sikh bodyguards on 31 October 1984. The result was a bloody genocide of thousands of Sikhs in Delhi. Countless Sikh females were raped and thousands of males, both children and adults, were openly set fire to on the streets of Delhi.

${ }^{2}$ Available at: https://www.gov.uk/government/uploads/system/uploads/attachment data/file/85522/castediscrimination.pdf

${ }^{\frac{d}{3} \text { Available at http://www.britishsikhreport.org/british-sikh-report-download-2013 }}$
} 
${ }^{4}$ See the 2017 report commissioned by the Sikh Federation UK: Miller, Phil (2017) Sacrificing Sikhs: The Need for an Investigation. Sikh Federation UK. Available at http://www.sikhfeduk.com/assets/files/Sacrificing-SikhsReport-2017.pdf

${ }^{5}$ See Singh, Jasjit (2017) "The idea, context, framing and realities of 'Sikh radicalisation' in Britain: Full

Report." Crest. Available at https://crestresearch.ac.uk/resources/sikh-radicalisation-full-report/

${ }^{6}$ Available at http://www.thesikhnetwork.com/the-manifesto/

${ }^{7}$ Available at http://www.britishsikhreport.org/british-sikh-report-download-2015/

${ }^{8}$ The UK Sikh Survey 2016 is the largest and most comprehensive of surveys undertaken to date on the British Sikh Community. Its analysis, by the Sikh Network, is based on the 4,500 respones to its survey, and is available at http://www.thesikhnetwork.com/uk-sikh-survey-2016/

${ }^{9}$ Further details about the campaign can be accessed at http://www.1984yesitsgenocide.org/ 